\title{
IDENTIFICATION OF SECONDARY METABOLITES AND ANTIDIARRHEAL ACTIVITY OF PIRDOT LEAVES ETHANOL EXTRACT (Saurauia vulcani Korth.) FROM WEST PAKPAK, NORTH SUMATERA PROVINCE, INDONESIA
}

\author{
K. Gurning ${ }^{1, *}$, R. Boangmanalu ${ }^{1}$, H.A. Simanjuntak ${ }^{1}$, N. Singarimbun ${ }^{2}$, \\ R. Rahmiati ${ }^{3}$ and W. Lestari ${ }^{4}$ \\ ${ }^{1}$ Department of Pharmacy, Sekolah Tinggi Ilmu Kesehatan Senior Medan, \\ Medan-20141, Indonesia \\ ${ }^{2}$ Departement of Midwifery, Sekolah Tinggi Ilmu Kesehatan Senior Medan, \\ Medan-20141, Indonesia \\ ${ }^{3}$ Departement of Biology, Universitas Medan Area, Medan-20112, Indonesia \\ ${ }^{4}$ Departement of Agrotechnology, Science and Technology Faculty, Universitas Labuhanbatu, \\ Rantauparapat-21415, Indonesia \\ *E-mail: kastagurning@gmail.com
}

\begin{abstract}
Pirdot (Saurauia vulcani Korth) is used by the people of West Pakpak in North Sumatera as medicinal ingredients. This study aims to identify secondary metabolite and to know the antidiarrheal activity of ethanol extract of pirdot leaves which tested on mice male which is induced by oleum rincini. The dosage variation of ethanol extract is 50 $\mathrm{mg} / \mathrm{kg}$ body weight, $100 \mathrm{mg} / \mathrm{kg}$ body weight, and $200 \mathrm{mg} / \mathrm{kg}$ body weight. Loperamide was used as a positive control with $2 \mathrm{mg} / \mathrm{kg}$ body weight dose, and $0.5 \% \mathrm{CMC} \mathrm{Na}$ as a negative control. Determination of antidiarrheal activity from the frequency of diarrhea, duration of diarrhea, and the consistency of the mice's feces which induced with oleum ricini by comparing the $\%$ inhibition from parameters. The results obtained showed that the extract dose $100 \mathrm{mg} / \mathrm{kg}$ body weight better than other variation of dose but not better than loperamide $2 \mathrm{mg} / \mathrm{kg}$ body weight as an antidiarrheal activity. Based on this research that the extract of pirdot leaves can be used as antidiarrheal with the right dose.
\end{abstract}

Keywords: Pirdot Leaves, Oleum ricini, Loperamide, and Antidiarrheal.

(C) RASĀYAN. All rights reserved

\section{INTRODUCTION}

Diarrhea is closely related to impaired physical development, cognitive, susceptibility to disease and cause of death especially in children under the age of 5 years old. This event generally occurs in developing countries such as Africa and Southeast Asia. Diarrhea is also referred to as gastroenteritis. ${ }^{3}$ Diarrhea is characterized by an increase in the frequency of bowel movements, soft-liquid stool conditions, and abdominal pain discomfort. ${ }^{1,2}$ Treatments are generally done by giving synthetic drugs such as loperamide, diphenoxylate, and antibiotics that give some side effects and drug resistance. ${ }^{2,4}$ The overcoming the side effects caused, it's important to find potential new drugs that can be obtained from natural ingredients. Traditionally treatment using natural ingredients from plants is considered safer from the side effects caused. ${ }^{5}$ Therefore, research into the discovery of active compounds from potential plants is considered to be important to study.

The pirdot plant (Saurauia vulcani Korth.) Is a type of plant, that is rich in potential bioactive compounds. Components of bioactive compounds found in pirdot leaves (Saurauia vulcani Korth.) Include alkaloids, flavonoids, saponins, triterpenoids and tannins. ${ }^{6}$ Empirical information of pirdot leaves have been traditionally used as a diabetes drug from boiled water. ${ }^{7}$ In vivo through pharmacological tests of extract extracts pirdot leaf ethanol has been proven to be an antidiabetic mellitus-induced antidiabetic mellitus in 
RASĀYAN J. Chem.

Vol. 13 | No. 4 |2385-2389| October - December | 2020

mice, ${ }^{8}$ and wound healing activity in hyperglycemic mice induced by Streptozotocin (STZ) ${ }^{9}$ and as an antioxidant. ${ }^{10}$ Other potentials of the bioactive compounds of pirdot leaves (Saurauia vulcani Korth.) as antidiarrheal have not been reported. Based on the description above, researchers are interested in testing the activity of pirdot leaves ethanol extract as an antidiarrheal which is tested on adult white male mice induced by oleum ricini.

\section{EXPERIMENTAL}

\section{Preparation of the plant}

A fresh sample of Pirdot leaves was taken and collected from the District of Salak (West Pakpak, North Sumatera Province, Indonesia) and authenticated by Herbarium Medanense, Faculty of Mathematics and Natural Science - the University of Sumatera Utara (No. 2380/MEDA/2018). Clean the sample, dried in drying cabinet at $40{ }^{\circ} \mathrm{C}$, powdered and stored at the Pharmacognosy Laboratory, Sekolah Tinggi Ilmu Kesehatan Medan.

\section{Preparation and Process of the Extract Plant}

$500 \mathrm{~g}$ pirdot leaves powder extracted with ethanol $96 \%$ with maceration method 5 days arrow at temperature room and occasionally stirred. After 5 days, filtered with Whatman paper No 1. Maceracied the residue with the same way twice. Evaporated the filtrate with evaporator rotary vacuum at $55^{\circ} \mathrm{C}$ to get the crude extract. ${ }^{11}$ Mixed the sticky extract then dried it in the oven at $40{ }^{\circ} \mathrm{C}$. put the dried powder in a bottle and store it in a desiccator in the laboratory at the temperature room.

\section{Phytochemical Screening}

The extract of pirdot leaves that soluble in ethanol analyzed of phytochemical compounds with standard methods. ${ }^{12,13,14}$

\section{Preparation the Mice}

The animals used for the research are adult male mice and health $( \pm 25 \mathrm{~g})$ from the House of Animal STIKes Senior Medan, Indonesia. Mice are placed in a standard cage at room temperature and fed with standard pellets and free water. This research gets permission and done this according to ethical norms from the National Health Research Ethics Committees (No. 0403/KEPH-FMIPA/2019). The mice are fasted for 18 hours not fed but given free access to water.

\section{Antidiarrheal Activity Testing of Pirdot Leaves Ethanol Extract (PLEE)}

The mice grouped into 5 that consists of:

Group 1: PLEE dose $50 \mathrm{mg} / \mathrm{kg}$ body weight

Group 2: PLEE dose of $100 \mathrm{mg} / \mathrm{kg}$ body weight

Group 3: PLEE dose of $200 \mathrm{mg} / \mathrm{kg}$ body weight

Group 4: Negative Control 0,5\% CMC Na

Group 5: Positive Control Loperamide $2 \mathrm{mg} / \mathrm{kg}$ body weight

The mice induced with $0,5 \mathrm{~mL}$ oleum ricini to get diarrhea by oral. ${ }^{15}$ After 2 hours of induction, then given the preparation test as much as the fit dosage that determined before, then do the observation per 30 minutes. The observation that has done included diarrhea frequently, duration of diarrhea, and consistency of the feces. The percentage of diarrhea determined by: ${ }^{16}$

\section{Statistic Analysis}

$$
\% \text { Inhibision Diarrheal }=\left(\frac{X_{\text {Control }}-X_{\text {Sample }}}{X_{\text {Control }}}\right) \times 100
$$

Data obtained analyzed with ANOVA and followed by Post hoc Tuckey using SPPS 16 version. All the data is stated as mean \pm SEM and $n=5$ with a level of trust $95 \%(\alpha<0,05)$.

\section{RESULTS AND DISCUSSION}

Crude extract ethanol of pirdot leaves that obtained means $136.24 \pm 0.05 \mathrm{~g}$. The result of phytochemical screening against ethanol extract of pirdot leaves shows the difference phytochemical compounds (Table$1)$. 
RASĀYAN J. Chem.

Vol. 13 | No. 4 |2385-2389| October - December | 2020

Table-1: Phytochemical Screening of PLEE

\begin{tabular}{c|c|c}
\hline Secondary Metabolites & Reagent & Ethanol Extract \\
\hline \multirow{2}{*}{ Alkaloids } & Mayer & Positive $(+)$ \\
\cline { 2 - 3 } & Dragenddroff & Positive $(+)$ \\
\cline { 2 - 3 } & Wagner & Positive $(+)$ \\
\hline Flavonoids & Shinoda test & Positive (+) \\
\hline Saponins & Foaming Test & Positive (+) \\
\hline Tannins & $\mathrm{FeCl}_{3} 1 \%$ & Negative (-) \\
\hline Triterpenoids & Liebermann Bouchard & Negative (-) \\
\hline Glycosides & Liebermann's Test & Positive (+) \\
\hline Anthraquinones & $\mathrm{NH}_{4} \mathrm{OH}$ test &
\end{tabular}

\section{Antidiarrheal Activity Test}

Antidiarrhea parameters testing from the ethanol extract of pirdot leaves which diarrhea frequency, duration of diarrhea, and consistency of diarrhea. The antidiarrheal activity was measured by in vivo method by using mice male (Mus musculus) as test animal. Mus musculus induced with $0,5 \mathrm{~mL}$ oleum ricini by oral so the mice get diarrhea (gastrointestinal). ${ }^{16,17}$

Tabel-2: PLEE Formulation against Antidiarrheal Activity Parameter that tested on Mice after 2 Hours Induction of Oleum Ricini

\begin{tabular}{l|c|c|c|c}
\hline \multirow{2}{*}{\multicolumn{1}{c|}{ Treatment }} & \multicolumn{4}{|c}{ Antidiarrheal Activity } \\
\cline { 2 - 5 } & $\begin{array}{c}\text { Frequency of } \\
\text { diarrhea }\end{array}$ & \% inhibition & $\begin{array}{c}\text { duration of } \\
\text { diarrhea }\end{array}$ & \% inhibition \\
\hline $0.5 \% \mathrm{CMC} \mathrm{Na}$ & $14.0 \pm 0.27$ & 0.00 & $272.4 \pm 0.11^{* *}$ & 0.00 \\
\hline PLEE $50 \mathrm{mg} / \mathrm{kg} \mathrm{bw}$ & $11.0 \pm 0.38^{*}$ & 21.43 & $230.2 \pm 0.15^{* *}$ & 15.5 \\
\hline PLEE $100 \mathrm{mg} / \mathrm{kg} \mathrm{bw}$ & $9.2 \pm 0.46^{*}$ & 34.29 & $149.1 \pm 0.20^{* *}$ & 45.3 \\
\hline PLEE $200 \mathrm{mg} / \mathrm{kg} \mathrm{bw}$ & $10.4 \pm 0.38^{*}$ & 25.71 & $203.2 \pm 0.15^{* *}$ & 25.40 \\
\hline Loperamide $2 \mathrm{mg} / \mathrm{kg} \mathrm{bw}$ & $8.4 \pm 0.37^{* *}$ & 40.00 & $120.2 \pm 0.22^{* *}$ & 55.88 \\
\hline
\end{tabular}

Description: the result is stated as average \pm SEM, $\mathrm{n}=5 ;{ }^{*} P<0,05,{ }^{* *} P<0,01$

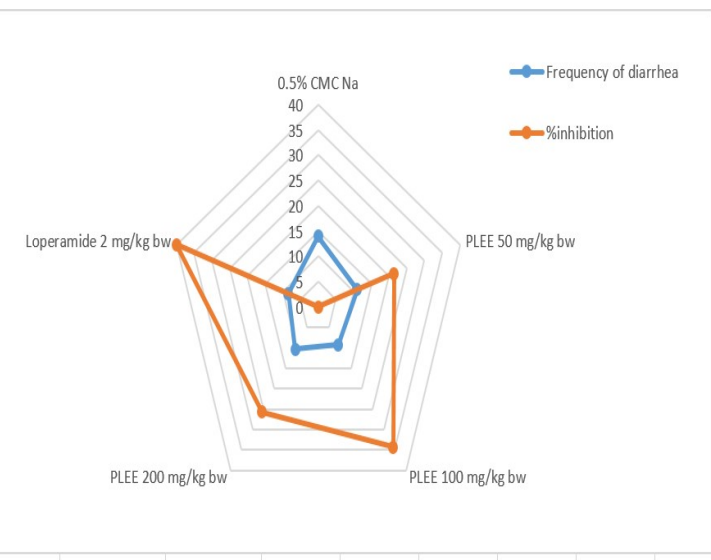

(a)

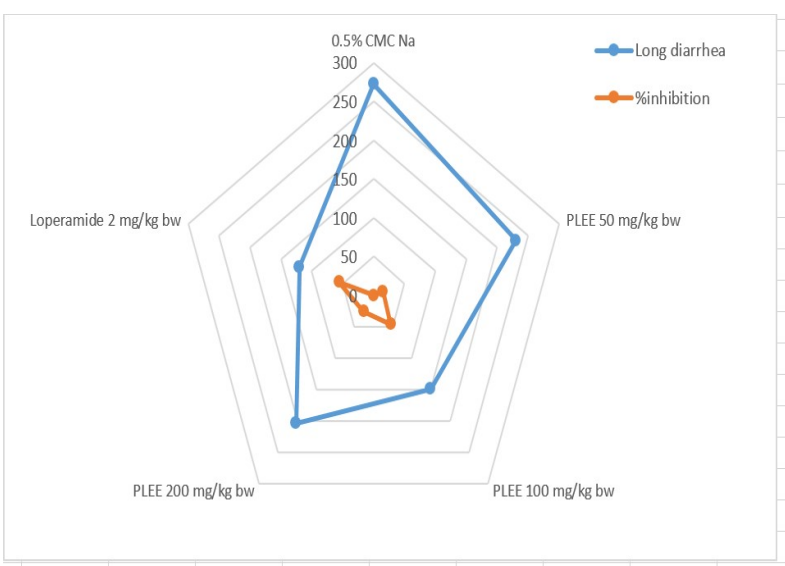

(b)

Fig-1: Antidiarrheal Activity of PLEE; (a) Diarrhea Frequency, and (b) Duration of Diarrhea

Based on Table-2 and Fig.-1a, ethanol extract of pirdot leaves shows activity against diarrhea frequency. The variation dose of PLEE showed that activity could significantly inhibit the frequency of diarrhea $21.43-34.29 \%(\mathrm{P}<0.05)$ and loperamide drugs were able to inhibit diarrhea by $40 \%$ with significance $(\mathrm{P}<0.01)$. Same as with the old parameters of diarrhea shows the activity as antidiarrheal. The variation dose of PLEE was able to inhibit $15.5-45.3 \%$ with significance $(\mathrm{P}<0.05)$ and loperamide drugs $55.88 \%$ 
RASĀYAN J. Chem.

Vol. 13 | No. 4 |2385-2389| October - December | 2020

with significance $(\mathrm{P}<0.01)$ (Fig.-1b). Observation of the consistency of diarrhea feces for variations at the dose of PLEE was observed in the form of mice's feces. Observation of feces form was carried out after 2 hours to induction of oleum ricini per 30 minutes observation. Form of the feces is divided into three categories including liquid feces 3, soft feces 2, and normal feces 1 . Diarrhea stool is categorized in the soft and liquid feces form. The observations are shown in Fig-2.

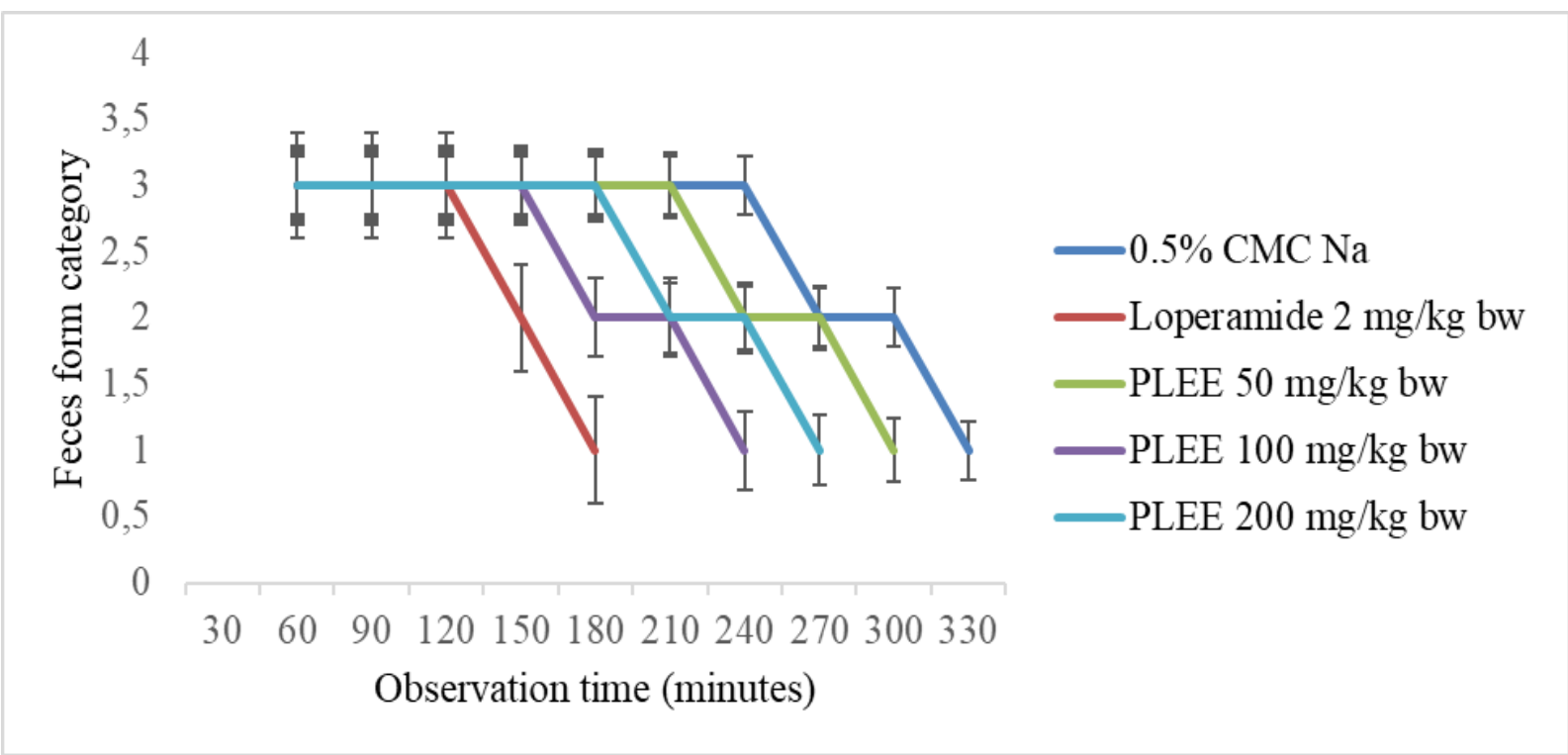

Fig-2. Antidiarrheal Activity of PLEE of Consistency of Diarrhea Feces

The best dose PLEE as antidiarrheal at $100 \mathrm{mg} / \mathrm{kg} \mathrm{bb}$. The effect increasing of extract concentration is not directly proportional to an increase in antidiarrheal activity, it can be seen between the concentration of $100 \mathrm{mg} / \mathrm{kg}$ bw with $200 \mathrm{mg} / \mathrm{kg}$ bw the concentration of $200 \mathrm{mg} / \mathrm{kg}$ bw decreases antidiarrheal activity. This is because of the possibility at a concentration of 100 $\mathrm{mg} / \mathrm{kg}$ bw has occupied all parts of the receptor. Besides that, the active compound contained in the extract may have an "agonist-antagonist" effect. For example, tannin active compounds with anthraquinone have opposite work effects, tanins effectively inhibit secretion of chloride-induced by forskoli and toxins while anthraquinone acts as a laxansia. ${ }^{18}$

\section{CONCLUSION}

Ethanol extract of pirdot leaves (Saurauia vulcani Korth) shows the activity as antidiarrheal that tested to male mice. Increase concentration ethanol extract of pirdot leaves not directly proportional to antidiarrheal activity. The best activity ethanol extract of pirdot leaves at $100 \mathrm{mg} / \mathrm{kg}$ body weight.

\section{ACKNOWLEDGMENT}

Thanks to Sekolah Tinggi Ilmu Kesehatan Senior Medan that support this research by giving support in using the laboratory as a research place.

\section{REFERENCES}

1. E.M. Birru, A.B. Asrie, G.M. Adinew and A. Tsegaw, BMC Complementary and Alternative Medicine, 16, 272(2016), DOI:10.1186/s12906-016-1252-4

2. G.N. Teke, J-R. Kuiate, V. Kuete, R.B.Teponno, L.A. Tapondjou and G. Vilarem, Indian Journal of Pharmacology, 42(3), 157(2010), DOI:10.4103/0253-7613.66839

3. N. Verma, A.P. Singh, A. Gupta, P.K. Sahu and C.V. Rao, Indian Journal of Pharmacology, 43(6), 689(2011), DOI: 10.4103/0253-7613.89827

4. M.K. Rahman, S. Barua, M.F. Islam, M.R. Islam, M.A. Sayeed, M.S. Parvin and M.E. Islam, Asian Pacific Journal of Tropical Biomedicine, 3(8), 639(2013), DOI:10.1016/S2221-1691(13)60129-X 
RASĀYAN J. Chem.

Vol. 13 | No. 4 |2385-2389| October - December | 2020

5. A. Hutapea, S. Hutahaean and S. Ilyas, Asian Journal of Pharmaceutical and Clinical Research, 11(11), 389(2018), DOI:10.22159/ajpcr.2018.v11i11.28316

6. B. Situmeang, A.R. Suparman, M. Kadarusman, A.S. Parumbak and T. Herlina, Jurnal Kimia Valensi, 4(2), 93(2018), DOI:10.15408/jkv.v4i2.7272

7. P. Sitorus, International Journal of ChemTech Research, 8(6), 789(2015).

8. G.A.b. Ginting, R. Rosidah, P. Sitorus and D. Satria, Journal of Innovations In Pharmaceutical and Biological Sciences, 5(3), 52(2018).

9. T.N. Lovena, U. Harahap, P. Sitorus and D. Satria, Journal of Innovations In Pharmaceutical and Biological Sciences, 5(3), 47(2018).

10. M. Belay, A.B. Asrie and Z.B. Wubneh, Evidence-Based Complementary and Alternative Medicine, Article ID 3037120, 1(2018), DOI:10.1155/2018/3037120

11. M.K. Rahman, M.A. Chowdhury, M.T. Islam, M.A. Chowdhury, M.E. Uddin and C.D. Sumi, Advances in Pharmacological Sciences, Article ID 257057, 1(2015), DOI:10.1155/2015/257057

12. R.A. Moushome, M.I. Akter and M.A. Aziz, Biomed Research International, Article ID 3167085 , 1(2016), DOI: $10.1155 / 2016 / 3167085$

13. R. Gul, S.U. Jan, S. Faridullah, S. Sherani and N. Jahan, The Scientific World Journal, Article ID 5873648,1(2017), DOI:10.1155/2017/5873648

14. G. Haro, I. Iksen, R.M. Rumanti, N. Marbun, R.P. Sari and R.P.J. Gultom, Rasāyan Journal of Chemistry, 11(1), 232(2018), DOI:10.7324/RJC.2018.1112011

15. B. Mokonnen, A.B. Asrie and Z.B. Wubneh, Evidence-Based Complementary and Alternative Medicine, Article ID 3037120, 1-10 (2018), DOI:10.1155/2018/3037120

16. N. Verma, A.P. Singh, P.K. Sahu and C.V. Rao, Indian Journal Pharmacology, 43(6), 689(2011), DOI: $10.4103 / 0253-7613.89827$

17. M. Sisay, E. Engidawork and W. Shibeshi, BMC Complementary and Alternative Medicine, 17(103), 1(2017), DOI: 10.1186/s12906-017-1625-3

18. M. Bakhriansyah, A. Febria and D. Rahmah. Majalah Farmasi Indonesia, 22(3), 158(2011).

[RJC-5984/2020] 